\title{
Pengaruh Kemampuan Koneksi dan Disposisi Matematis Terhadap Hasil Belajar Siswa SMA Negeri 2 Balikpapan
}

\author{
Darin Nadhifah ${ }^{1}$, Ganjar Susilo ${ }^{2}$, Besse Intan Permatasari ${ }^{3}$ \\ ${ }^{1}$ Universitas Balikpapan, ${ }^{2}$ Universitas Balikpapan, ${ }^{3}$ Universitas Balikpapan \\ ${ }^{1}$ nadhifahdarin@gmail.com, ${ }^{2}$ ganjar.susilo@uniba-bpn.ac.id, \\ ${ }^{3}$ besse.intan@uniba-bpn.ac.id
}

\begin{tabular}{l}
\hline \hline Article Info \\
\hline Article history: \\
Received Mar $8^{\text {th }}, 2019$ \\
Revised April $26^{\text {th }}, 2019$ \\
Accepted April $28^{\text {th }}, 2019$ \\
\hline
\end{tabular}

Keywords:

Mathematical

Connection Ability;

Mathematical

Disposition;

Mathematics Learning

Outcomes

Abstract

The purpose of this research was would know if there are effect mathematics connection ability and disposition to mathematics achievement student class XI SMA Negeri 2 Balikpapan in the Academic Year of 2017/2018. The research used in this study is quantitative and the type of ex-post facto research. The research sampling technique uses cluster random sampling. Data collection techniques used in this study were in the form of tests and questionnaires. Data analysis techniques using multiple linear regression analysis with hypothesis testing using f-test and t-test as a partial test to determine the independent variable mathematical connection $\left(X_{1}\right)$ on learning outcomes $(Y)$ and mathematical disposition independent variable $\left(X_{2}\right)$ on mathematics learning outcomes $(Y)$, but before testing the hypothesis it is necessary to test the classical assumptions of normality test, linearity test, independent test, multicollinearity test, and heteroscedasticity test. The results in this study are 1) there is an influence of mathematical connection ability and mathematical disposition on mathematics learning outcomes; 2) there is an influence of mathematical connection ability on mathematics learning outcomes; 3) there is an influence of mathematical disposition on the learning outcomes of mathematics.

Kata Kunci:

Kemampuan Koneksi Matematis;

\section{Abstrak}

Penelitian ini bertujuan untuk mengetahui pengaruh kemampuan koneksi matematis dan disposisi matematis terhadap hasil belajar matematis siswa kelas XI SMA 
24| Nadhifah, Susilo, Permatasari: Pengaruh Kemampuan Koneksi Matematis dan Disposisi ...

Disposisi Matematis;

Hasil Belajar

Matematika
Negeri 2 Balikpapan Tahun Ajaran 2017/2018 baik secara bersama-sama maupun secara parsial. Pendekatan yang digunakan dalam penelitian ini pendekatan kuantitatif dan jenis penelitian ex-post facto. Teknik pengambilan sampel penelitian menggunakan cluster random sampling. Teknik pengumpulan data yang digunakan dalam penelitian ini berupa tes dan angket. Teknik analisis data menggunakan analisis regresi linier berganda dengan uji hipotesisnya menggunakan uji $\mathrm{F}$ dan uji $\mathrm{t}$ sebagai uji parsial untuk mengetahui variabel bebas koneksi matematis $\left(\mathrm{X}_{1}\right)$ terhadap hasil belajar $(\mathrm{Y})$ serta variabel bebas disposisi matematis $\left(X_{2}\right)$ terhadap hasil belajar matematika (Y), namun sebelum dilakukan uji hipotesis perlu dilakukan uji asumsi klasik yaitu uji normalitas, uji linieritas, uji independen, uji multikolinearitas, dan uji heterokedastisitas. Hasil dalam penelitian ini adalah 1) terdapat pengaruh kemampuan koneksi matematis dan disposisi matematis terhadap hasil belajar matematika; 2) terdapat pengaruh kemampuan koneksi matematis terhadap hasil belajar matematika; 3) terdapat pengaruh disposisi matematis terhadap hasil belajar matematika.

\section{PENDAHULUAN}

Pendidikan sebagai bentuk kegiatan manusia dalam kehidupannya juga menempatkan tujuan sebagai sesuatu yang hendak dicapai, baik tujuan yang dirumuskan itu bersifat abstrak sampai pada rumusanrumusan yang dibentuk secara khusus untuk memudahkan pencapaian yang lebih tinggi. Cita-cita atau tujuan yang ingin dicapai harus dinyatakan secara jelas, sehingga semua komponen pendidikan terutama pelaksana pendidikan harus memahami target atau sasaran pendidikan, sehingga mampu mengembangkan potensi siswa menjadi manusia yang beriman dan bertaqwa kepada Tuhan Yang Maha Esa, berakhlak mulia, sehat berilmu, cakap, kreatif, dan mandiri (Hasbullah, 2009, p.11). Sekolah juga turut berperan serta dalam mewujudkan tujuan pendidikan nasional, karena siswa menghabiskan waktu kurang lebih sembilan jam per hari di sekolah. Proses belajar yang dilakukan siswa sangat dipengaruhi oleh guru dan orang tua serta sarana dan sumber belajar yang 
digunakan, sehingga berhasil atau tidak suatu pembelajaran sangat bergantung adanya komponen tersebut. Selain itu pula ada faktor-faktor internal dari siswa juga mempengaruhi berhasil atau tidaknya pembelajaran yang ditinjau dari hasil belajar. Sehingga banyak faktor yang dapat mempengaruhi hasil belajar siswa. Faktor-faktor tersebut diantaranya adalah kemampuan-kemampuan dasar matematika yang harus dimiliki siswa serta sikap positif yang dimiliki siswa dalam mempelajari matematika.

Matematika merupakan salah satu aspek yang tak lepas dari pendidikan, sedangkan pendidikan merupakan salah satu komponen utama dalam menentukan tingkat suatu bangsa. Apabila para siswa berusaha menyukai matematika dan diharapkan akan berdampak pada pencapaian prestasi yang unggul. Para siswa diharapkan akan menjadi tertarik dan tertantang untuk berusaha memahami matematika lebih dalam, karena dalam pikiran para siswa sudah tertanam bahwasannya, matematika sangat akrab dengan dunia aktivitas sehari-hari. Namun hal ini berbeda dengan kondisi yang terjadi di SMA Negeri 2 Balikpapan. Berdasarkan wawancara yang dilakukan dengan salah satu guru matematika di SMA Negeri 2 Balikpapan yang mengatakan bahwa siswa kurang mampu mengerjakan soal-soal Higher Order Thinking Skills (HOTS) yang mengharuskan menggunakan penalaran dan koneksi matematika. HOTS adalah kemampuan berpikir kritis, logis, reflektif, metakognitif, dan berpikir kreatif yang merupakan kemampuan berpikir tingkat tinggi. Merujuk pada National Council of Teachers of Mathematics (2000, p. 4) ada lima standar proses yaitu pemecahan masalah matematika, penalaran masalah matematika, komunikasi matematika, koneksi matematika, dan representasi matematika.

Pada lima standar tersebut yang menjadi sorotan dalam pembelajaran matematika adalah kemampuan siswa dalam menghubungkan konsep-konsep matematika baik antar konsep dalam matematika itu sendiri maupun mengaitkan konsep matematika dengan konsep dalam bidang lainnya. Bila siswa bisa menghubungkan ide matematika, pemahaman para siswa akan lebih dalam. Di samping itu 
26| Nadhifah, Susilo, Permatasari: Pengaruh Kemampuan Koneksi Matematis dan Disposisi ...

guru matematika juga mengatakan ada beberapa siswa yang sudah meyakini bahwa memiliki kemampuan matematika rendah dan itu menjadi masalah bagi guru di sekolah tersebut. Beberapa siswa beranggapan saat berada satu lingkungan dengan siswa-siswa dengan kemampuan matematika rendah, maka para siswa tersebut juga memiliki kemampuan matematika yang rendah. Sehingga para siswa tersebut tidak mau menggali lagi kemampuan matematika dan tidak memiliki sikap positif terhadap matematika. Kurang memiliki keyakinan akan kemampuan matematika, tidak mau menggali kemampuan matematika, dan tidak memiliki sikap positif terhadap matematika dapat dikatakan siswa kurang memiliki disposisi matematis.

Disposisi matematis adalah keinginan, kesadaran, kecenderungan, dan dedikasi kuat pada diri siswa untuk berpikir dan berbuat secara matematika dengan cara yang positif. Dalam menghadapi era informasi dan suasana bersaing yang semakin ketat, dalam mempelajari kompetensi matematika di atas, siswa dan mahasiswa perlu memiliki kemampuan berpikir matematika tingkat tinggi, sikap kritis, kreatif dan cermat, obyektif dan terbuka, menghargai keindahan matematika, serta rasa ingin tahu dan senang belajar matematika (Sumarmo, Hidayat, Zukarnaen, Hamidah, \& Sariningsih, 2011, p. 18).

Terdapat beberapa penelitian mengenai koneksi dan disposisi matematis, diantaranya adalah Izzati (2017, p. 38) dengan hasil penelitian terdapat pengaruh koneksi dan disposisi matematis terhadap hasil belajar. Mandur, Sadra, \& Suparta (2013, p. 9) telah membuktikan bahwa kemampuan koneksi, kemampuan representasi, dan disposisi matematis berkontribusi secara signifikan terhadap prestasi belajar matematika siswa kelas XI IPA di Kabupaten Manggarai, baik secara langsung maupun tidak langsung. Hal ini dapat terjadi karena dalam pembelajaran matematika, koneksi matematis merupakan salah satu kemampuan esensial yang harus dimiliki oleh siswa, sedangkan disposisi matematis merupakan salah satu faktor penunjang keberhasilan belajar matematika siswa karena merupakan sikap positif terhadap matematika. Selain itu, Lestari, Suharto, \& Fatahillah (2016, P. 42) mengungkapkan bahwa 
walaupun disposisi matematis berpengaruh terhadap hasil belajar namun hanya memberikan pengaruh sebesar 19\%, sedangkan sisanya sebesar $81 \%$ dipengaruhi oleh faktor lainnya yaitu kemampuan siswa dalam memahami materi integral tak tentu, minat, kecerdasan, kemampuan kognitif, guru dan kondisi panca indera. Penelitian terdahulu kemampuan koneksi matematis hanya sebatas meneliti hubungan topik/konsep matematika yang sedang dibahas dengan konsep matematika lainnya, dengan pelajaran lain atau disiplin ilmu lainnya sedangkan disposisi matematis hanya sebatas melihat seberapa besar siswa mampu menggali kemampuan dalam pemecahan masalah matematika dan menanggapi dengan sikap positif. Sehingga perlu dilakukan secara mendalam kemampuan koneksi matematis dan disposisi matematis siswa untuk memecahkan masalah matematika yang berkaitan dengan HOTS. Penggunaan pemecahan masalah matematika dengan HOTS mampu merangsang kemampuan koneksi matematis dan disposisi matematis lebih baik sehingga hasil belajar matematika siswa menjadi lebih baik. Oleh karena itu, pada penelitian akan dicari apakah kemampuan koneksi matematis dan disposisi matematis berpengaruh terhadap hasil belajar matematika siswa baik secara bersama-sama maupun secara parsial dengan studi kasus pada siswa kelas XI SMA Negeri 2 Balikpapan Tahun Ajaran 2017/2018.

\section{METODE PENELITIAN}

Penelitian ini menggunakan pendekatan kuantitatif, dimana pendekatan kuantitatif adalah suatu pendekatan penelitian yang secara primer menggunakan paradigma postpositivist. Postpositivist mencerminkan filosofi deterministik dalam hal sebab-sebab yang mungkin menentukan efek atau hasil dalam mengembangkan ilmu pengetahuan (seperti pemikiran tentang sebab akibat, reduksi kepada variabel, hipotesis, dan pertanyaan spesifik, menggunakan pengukuran dan observasi, serta pengujian teori), menggunakan strategi penelitian seperti eksperimen dan data survey yang memerlukan data statistik (Emzir, 2013, p. 28). Jenis penelitian ini adalah penelitian ex-post facto, 
28| Nadhifah, Susilo, Permatasari: Pengaruh Kemampuan Koneksi Matematis dan Disposisi ...

dimana penelitian ex-post facto merupakan penelitian yang bertujuan menemukan penyebab yang memungkinkan perubahan perilaku, gejala atau fenomena yang disebabkan oleh suatu peristiwa, perilaku atau halhal yang menyebabkan perubahan pada variabel bebas yang secara keseluruhan sudah terjadi. Perubahan yang ingin diketahui adalah pengaruh kemampuan matematis $\left(X_{1}\right)$ dan disposisi matematis $\left(X_{2}\right)$ sebagai variabel bebas terhadap hasil belajar matematika siswa (Y) sebagai variabel terikatnya. Selain itu pula dalam penelitian ini juga ingin mencari pengaruh parsial kemampuan matematis $\left(\mathrm{X}_{1}\right)$ terhadap hasil belajar matematika siswa serta pengaruh disposisi matematis $\left(\mathrm{X}_{2}\right)$ terhadap hasil belajar matematika siswa di SMA Negeri 2 Balikpapan.

Penelitian ini bertempat di SMA Negeri 2 Balikpapan yang terletak di Jalan Soekarno Hatta Strat 4, Gunung Samarinda, Balikpapan Utara, Kota Balikpapan, Kalimantan Timur. Populasi penelitian ini adalah seluruh siswa kelas XI SMA Negeri 2 Balikpapan Tahun Ajaran 2017/2018 dengan jumlah populasi 294 siswa. Teknik pengambilan sampel adalah dengan menggunakan cluster random sampling adalah sampel akan diacak dimana tiap-tiap unit dikumpulkan sebagai kumpulan atau cluster. Karena dalam sekolah seluruh siswa sudah dibagi ke dalam beberapa kelas, peneliti akan membuat kertas berisi nama kelas lalu diacak bersama-sama dan nama kelas yang keluar akan menjadi sampel penelitian.

Arikunto (2013, p. 116) menyatakan bahwa jika jumlah populasi lebih dari 100, maka dapat diambil 10\%-15\%, 20\%-25\%, atau lebih. Jumlah sampel yang digunakan dalam penelitian ini adalah 25\% dari jumlah populasi yaitu 73,5 yang dibulatkan menjadi 74 sampel. Banyak sampel yang akan diambil sebanyak empat kelas. Sampel yang diambil dari kelas MIPA/IPS 1 dan MIPA/IPS 6 dengan jumlah 78 siswa. Teknik pengumpulan data penelitian ini adalah (1) wawancara tidak terstruktur yang digunakan peneliti sebagai wawancara awal di lapangan yang diperoleh permasalahan berupa kesulitan siswa dalam mengerjakan soal dan kepercayaan diri dan sikap positif siswa terhadap mata pelajaran matematika yang akan dijadikan latar belakang masalah dalam penelitian; 
(2) tes, diberikan kepada siswa sebanyak dua kali yaitu untuk mengukur kemampuan koneksi matematis sebanyak lima butir soal uraian dengan rentang skor 0-100, serta tes hasil belajar matematika sebanyak 13 butir soal pilihan ganda dengan rentang skor 0-100; (3) kuesioner, diberikan kepada siswa untuk mengetahui kemampuan disposisi matematis siswa sebanyak 27 butir kuesioner dengan menggunakan skala Likert dengan rentang skor 1-5; (4) dokumentasi, digunakan untuk memberikan keterangan populasi, serta sampel penelitian dan pelaksanaan penelitian. Teknik analisis data yang digunakan dalam penelitian ini adalah analisis regresi berganda dengan terlebih dahulu menggunakan uji asumsi klasik pada analisis regresi ganda yaitu uji normalitas, uji linieritas, uji independen, uji multikolinearitas, dan uji heterokedastisitas. Selanjutnya dilakukan uji hipotesis menggunakan uji-f serta dicari pula koefisien determinasi $\left(\mathrm{R}^{2}\right)$ yang berfungsi untuk memprediksi dan melihat seberapa besar kontribusi pengaruh yang diberikan variabel bebas $\left(\mathrm{X}_{1}\right.$ dan $\left.\mathrm{X}_{2}\right)$ secara simultan terhadap variabel terikat (Y). Jika ada pengaruh secara simultan pada variabel bebas dan terikat maka perlu dilakukan uji parsial dengan menggunakan uji-t.

\section{HASIL PENELITIAN DAN PEMBAHASAN}

Penelitian yang dilakukan di SMA Negeri 2 Balikpapan menggunakan tiga sumber data yang berasal dari tes kemampuan koneksi matematis, angket disposisi matematis, dan tes hasil belajar. Pengumpulan data dilakukan secara berkala terbagi menjadi dua pertemuan dikarenakan waktu yang tersedia sangat terbatas apabila siswa mengerjakan dua tes dalam satu pertemuan. Pertemuan pertama dilaksanakan tanggal 22 Mei 2018 digunakan untuk tes koneksi matematis dan angket disposisi matematis. Pertemuan kedua dilaksanakan tanggal 25 Mei 2018 digunakan untuk tes hasil belajar matematika. Pada penelitian ini sampel berjumlah 74 siswa. Sumber data yang digunakan peneliti adalah tes dan angket, tes digunakan untuk mengukur kemampuan koneksi matematis siswa dan hasil belajar matematika siswa sedangkan angket digunakan untuk mengukur disposisi matematis siswa. 
30| Nadhifah, Susilo, Permatasari: Pengaruh Kemampuan Koneksi Matematis dan Disposisi ...

Berikut adalah tabel deskripsi data hasil tes koneksi matematis, disposisi matematis, dan hasil belajar matematika.

Tabel 1. Deskripsi Data Hasil Tes Koneksi Matematis, Disposisi Matematis, dan Hasil Belajar Matematika

\begin{tabular}{lccc}
\hline \multicolumn{1}{c}{ Variabel } & $\begin{array}{c}\text { Koneksi } \\
\text { Matematis }\left(\mathbf{X}_{\mathbf{1}}\right)\end{array}$ & $\begin{array}{c}\text { Disposisi } \\
\text { Matematis }\left(\mathbf{X}_{\mathbf{2}}\right)\end{array}$ & $\begin{array}{c}\text { Hasil } \\
\text { Belajar } \\
\text { Matematika } \\
(\mathbf{Y})\end{array}$ \\
\hline Rata-rata & 53,513 & 65,527 & 58,716 \\
Median & 55 & 66 & 62 \\
Modus & 70 & 64 & 54 \\
Deviasi standar & 21,76 & 11,602 & 16,747 \\
Variansi & 473,787 & 134,609 & 280,480 \\
Skor maksimum & 100 & 100 & 92 \\
Skor minimum & 10 & 31 & 23 \\
\hline
\end{tabular}

Tes koneksi matematis berbentuk soal uraian dengan 5 butir soal dan diberikan skor sesuai dengan pedoman penskoran yang telah dibuat dengan tingkat kesukaran yang berbeda di tiap soal. Pada angket disposisi matematis menggunakan 27 butir angket. Butir angket dibuat dan disertai pilihan jawaban yang dibagi lima skala yaitu SS (Sangat Setuju), S (Setuju), CS (Cukup Setuju), TS (Tidak Setuju), dan STS (Sangat Tidak Setuju) dan skala-skala tersebut diberi skor yang telah ditentukan. Sedangkan tes yang digunakan untuk mengukur hasil belajar matematika berbentuk soal pilihan ganda sebanyak 13 butir soal dengan tingkat kesukaran yang berbeda-beda di tiap soalnya. Pada tabel 1, dapat diketahui rata-rata koneksi matematis siswa diperoleh 53,513, disposisi matematis siswa diperoleh 65,527 dan hasil belajar matematika diperoleh 58,716 . Median atau nilai tengah pada koneksi matematis siswa diperoleh 55, disposisi matematis siswa 66, dan hasil belajar matematika 62. Modus pada koneksi matematis siswa diperoleh 70 , disposisi matematis diperoleh 64, dan hasil belajar diperoleh 54. Deviasi standar koneksi matematis 21,76, disposisi matematis 11,602, dan hasil belajar matematika diperoleh 
16,747. Variansi pada koneksi matematis diperoleh 473,787, disposisi matematis 134,609 , dan hasil belajar matematika diperoleh 280,480. Skor maksimum yang diperoleh pada koneksi matematis adalah 100, disposisi matematis 100, dan hasil belajar matematika diperoleh 92. Skor minimum pada koneksi matematis diperoleh 10, disposisi matematis 31, dan hasil belajar diperoleh 23 .

Kemudian untuk mengetahui apakah terdapat pengaruh kemampuan koneksi matematis dan disposisi matematis terhadap hasil belajar matematika baik secara bersama-sama maupun secara parsial. Hasil penelitian telah dianalisis dengan regresi linier ganda dengan menggunakan uji $\mathrm{f}$ dan uji $\mathrm{t}$ untuk menjawab rumusan masalah pada penelitian ini. Sebelum melakukan uji hipotesis peneliti melakukan uji asumsi klasik dalam penelitian ini yaitu uji normalitas, uji linieritas, uji independen, uji multikolinearitas, dan uji heterokedastisitas. Berikut disajikan uji asumsi klasik analisis regresi berganda.

\begin{tabular}{|c|c|c|c|}
\hline Variabel & $\begin{array}{c}\text { Nilai } \\
\text { Sig. }\end{array}$ & Keputusan uji & Simpulan \\
\hline $\begin{array}{l}\text { Kemampuan } \\
\text { matematis }\left(\mathrm{X}_{1}\right) \text {, disposisi } \\
\text { matematis }\left(\mathrm{X}_{2}\right) \text { terhadap } \\
\text { hasil belajar matematika } \\
(\mathrm{Y})\end{array}$ & 0,073 & $\begin{array}{l}\mathrm{H}_{0} \quad \text { diterima } \\
\text { karena nilai sig. } \\
>\alpha=0,05\end{array}$ & $\begin{array}{l}\text { Sampel } \\
\text { berasal dari } \\
\text { populasi yang } \\
\text { berdistribusi } \\
\text { normal }\end{array}$ \\
\hline
\end{tabular}

Berdasarkan tabel 2 diperoleh nilai sig. yaitu 0,073, karena nilai sig. $>\alpha$, maka $\mathrm{H}_{0}$ diterima sehingga dapat diketahui sampel data pada variabel kemampuan koneksi matematis $\left(\mathrm{X}_{1}\right)$, disposisi matematis $\left(\mathrm{X}_{2}\right)$ terhadap hasil belajar matematika (Y) berasal dari populasi yang berdistribusi normal.

Tabel 3. Hasil Uji Linieritas

\begin{tabular}{lccccc}
\hline Variabel & Nilai Sig. & $\begin{array}{c}\text { Keputusan } \\
\text { uji }\end{array}$ & Simpulan \\
\hline Kemampuan & koneksi & 0,238 & $\mathrm{H}_{0}$ & diterima & Terdapat hubungan
\end{tabular}


32| Nadhifah, Susilo, Permatasari: Pengaruh Kemampuan Koneksi Matematis dan Disposisi ...

\begin{tabular}{|c|c|c|c|}
\hline \multicolumn{2}{|l|}{$\begin{array}{l}\text { matematis }\left(\mathrm{X}_{1}\right) \text { terhadap } \\
\text { hasil belajar matematika } \\
(\mathrm{Y})\end{array}$} & $\begin{array}{l}\text { karena nilai } \\
\text { sig. }>\alpha=0,05\end{array}$ & $\begin{array}{lr}\text { linier } & \text { koneksi } \\
\text { matematis } & \text { siswa } \\
\text { terhadap } & \text { hasil } \\
\text { belajar siswa } & \end{array}$ \\
\hline $\begin{array}{l}\text { Disposisi matematis }\left(\mathrm{X}_{2}\right) \\
\text { terhadap hasil belajar } \\
\text { matematika }(\mathrm{Y})\end{array}$ & 0,584 & $\begin{array}{l}\mathrm{H}_{0} \quad \text { diterima } \\
\text { karena nilai } \\
\text { sig. }>\alpha=0,05\end{array}$ & $\begin{array}{lr}\text { Terdapat } & \text { hubungan } \\
\text { linier } & \text { koneksi } \\
\text { matematis } & \text { siswa } \\
\text { terhadap } & \text { hasil } \\
\text { belajar siswa } & \end{array}$ \\
\hline
\end{tabular}

Berdasarkan tabel 3 untuk hipotesis pertama didapatkan nilai signifikansi $0,238(0,238>0,05)$, maka $\mathrm{H}_{0}$ diterima maka terdapat hubungan linier kemampuan koneksi matematis dan hasil belajar matematika. Untuk hipotesis kedua didapatkan nilai signifikansi 0,584 $(0,584>0,05)$, maka $\mathrm{H}_{0}$ diterima maka terdapat hubungan linier disposisi matematis dan hasil belajar matematika.

Tabel 4. Hasil Uji Independen

\begin{tabular}{lrlll}
\hline \multicolumn{1}{c}{ Variabel } & $\begin{array}{c}\text { Nilai } \\
\text { Durbin- } \\
\text { Watson }\end{array}$ & Keputusan uji & \multicolumn{1}{c}{ Simpulan } \\
\hline Kemampuan koneksi & & $\mathrm{H}_{0}$ diterima karena & \\
matematis $\left(\mathrm{X}_{1}\right)$, disposisi & & nilai $\quad$ Durbin- & Tidak terdapat \\
matematis $\left(\mathrm{X}_{2}\right)$ & terhadap & 1,748 & Watson diantara & autokorelasi pada \\
hasil belajar matematika & & $\mathrm{dU}=1,6785$ dan 4- & data yang diuji \\
$(\mathrm{Y})$ & & $\mathrm{dL}=2,3215$ & \\
\hline
\end{tabular}

Berdasarkan tabel 4 dilakukan perhitungan menggunakan uji Durbin-Watson didapatkan nilai $\mathrm{dw}$ adalah 1,748. Nilai tersebut akan dibandingkan dengan tabel Durbin-Watson dengan nilai tabel $\alpha=5 \%$, jumlah sampel $(n)=74$ dan variabel independen $(k)=2$ maka didapatkan nilai tabel Durbin-Watson yaitu $\mathrm{dL}=1,5677 \mathrm{dan} \mathrm{dU}=1,6785$. Nilai $\mathrm{dw}$ berada diantara nilai dU dan 4-dU $(1,6785<1,748<2,3215)$ oleh karena itu dapat disimpulkan tidak ada autokorelasi pada data yang diuji. 
Tabel 5. Hasil Uji Multikolinieritas

\begin{tabular}{|c|c|c|c|c|}
\hline Variabel & Tolerance & $\begin{array}{c}\text { Variance } \\
\text { Inflation } \\
\text { Faktor (VIF) }\end{array}$ & $\begin{array}{c}\text { Keputusan } \\
\text { uji }\end{array}$ & Simpulan \\
\hline $\begin{array}{l}\text { Kemampuan } \\
\text { koneksi matematis } \\
\left(\mathrm{X}_{1}\right)\end{array}$ & 0,998 & 1,002 & $\begin{array}{l}\text { Karena nilai } \\
\text { tolerance > } \\
0,10 \text { atau VIF }\end{array}$ & $\begin{array}{l}\text { Tidak terjadi } \\
\text { multikolinieritas }\end{array}$ \\
\hline $\begin{array}{l}\text { Disposisi } \\
\text { matematis }\left(\mathrm{X}_{2}\right)\end{array}$ & 0,998 & 1,002 & $\begin{array}{l}<10 \text {, maka } \mathrm{H}_{0} \\
\text { diterima }\end{array}$ & $\begin{array}{l}\text { pada data yang } \\
\text { diuji }\end{array}$ \\
\hline
\end{tabular}

Berdasarkan tabel 5 diperoleh hasil tolerance sebesar 0,998 dan VIF 1,002. Nilai tolerance lebih besar dari $0,10(0,998>0,10)$ dan nilai VIF kurang dari $10(1,002<10)$ oleh karena itu $\mathrm{H}_{0}$ diterima. Maka dapat disimpulkan bahwa tidak terjadi multikolinieritas pada data yang diuji.

Tabel 6. Hasil Uji Heterokedastisitas

\begin{tabular}{|c|c|c|c|}
\hline Variabel & $\begin{array}{c}\text { Nilai } \\
\text { Sig. }\end{array}$ & Keputusan uji & Simpulan \\
\hline $\begin{array}{l}\text { Kemampuan koneksi } \\
\text { matematis }\left(\mathrm{X}_{1}\right) \text { dan } \\
\text { Disposisi matematis } \\
\left(\mathrm{X}_{2}\right)\end{array}$ & 0,450 & $\begin{array}{l}\text { Karena nilai sig. } \\
\text { dengan uji Glejser } \\
>\alpha=0,05 \text { maka } \mathrm{H}_{0} \\
\text { diterima }\end{array}$ & $\begin{array}{l}\text { Tidak terjadi } \\
\text { heterokedastisitas pada } \\
\text { data yang diuji }\end{array}$ \\
\hline
\end{tabular}

Berdasarkan tabel 6, dalam perhitungan uji Glejser didapatkan nilai signifikansi sebesar 0,45. Nilai signifikansi lebih besar dari 0,05 (0,45 > 0,05) oleh karena itu $\mathrm{H}_{0}$ diterima. Maka dapat disimpulkan bahwa tidak terjadi heterokedastisitas pada data yang diuji.

Berdasarkan uji asumsi klasik pada regresi berganda yang telah terpenuhi maka dilakukan uji hipotesis penelitian. Pada penelitian model regresi berganda terdapat dua variabel bebas yaitu kemampuan koneksi matematis $\left(\mathrm{X}_{1}\right)$ dan disposisi matematis $\left(\mathrm{X}_{2}\right)$ dan satu variabel terikat yaitu hasil belajar matematika (Y). Dalam uji hipotesis dilakukan dua uji yaitu uji koefisien korelasi ganda (uji f) dan uji parsial uji (t).

Berdasarkan hasil analisis regresi diketahui nilai koefisien determinasi ( $\mathrm{R}$ square) sebesar 0,902 atau 90,2\%. Hal tersebut 
34| Nadhifah, Susilo, Permatasari: Pengaruh Kemampuan Koneksi Matematis dan Disposisi ...

menunjukkan bahwa variabel kemampuan koneksi dan disposisi matematis berpengaruh terhadap hasil belajar matematika sebesar 90,2\% dan sisanya dipengaruhi oleh variabel-variabel lain di luar penelitian ini. Presentase tersebut dapat dikatakan tinggi. Berdasarkan hal tersebut dapat diketahui bahwa kemampuan koneksi matematis dan disposisi matematis memiliki kontribusi yang tinggi terhadap hasil belajar matematika. Hal tersebut juga dapat dilihat dari model regresi linier berganda pada penelitian ini yaitu $Y=10,533+0,724 X_{1}+0,144 X_{2}$. Pada persamaan regresi berganda yang diperoleh jika diasumsikan siswa memiliki skor variabel bebas koneksi matematis $\left(\mathrm{X}_{1}\right)$ adalah 0 atau variabel kemampuan koneksi matematis tidak ada skornya dan variabel bebas disposisi matematis $\left(\mathrm{X}_{2}\right)$ diasumsikan siswa memiliki skor 0 atau variabel disposisi matematis tidak ada sehingga dapat diketahui bahwa prediksi hasil belajar matematika mendapatkan skor 10,533. Oleh karena itu, setiap penambahan 1 poin variabel kemampuan koneksi matematis meningkatkan skor hasil belajar siswa sebesar 0,724 begitu pula pada variabel disposisi matematis setiap penambahan 1 poin variabel disposisi matematis akan meningkat skor hasil belajar matematika sebesar 0,144.

Setelah dilakukan perhitungan uji simultan (uji f) untuk menjawab rumusan masalah didapatkan hasil nilai signifikansi 0,000 dan nilai tersebut kurang dari $0,05(0,000<0,05)$ yang menunjukan terdapat pengaruh antara kemampuan koneksi matematis dan disposisi matematis terhadap hasil belajar matematika. Setelah dilakukan uji secara bersamasama peneliti melanjutkan dengan uji secara pasial atau uji $t$ dan didapatkan hasil nilai signifikansi untuk kemampuan koneksi matematis sebesar 0,000. Nilai signifikansi kemampuan koneksi matematis kurang dari $0,05(0,000<0,05)$ yang menunjukkan terdapat pengaruh antara kemampuan koneksi matematis terhadap hasil belajar matematis. Sedangkan untuk nilai signifikansi disposisi matematis sebesar 0,009. Nilai signifikansi disposisi matematis kurang dari 0,05 $(0,009<0,05)$ oleh karena itu yang menunjukkan terdapat pengaruh antara disposisi matematis terhadap hasil belajar matematika. 
Pada saat penelitian berlangsung setelah peneliti selesai mengumpulkan data, beberapa siswa meminta soal beserta jawaban untuk dipelajari di rumah hal tersebut menunjukan bahwa para siswa tersebut memiliki sikap positif terhadap matematika atau yang dalam penelitian ini disebut disposisi matematis. Sikap positif ini ditunjukkan oleh siswa ketika mereka mendapatkan skor penilaian hasil belajar yang diperoleh dari tes kemampuan koneksi matematis. Ada pula beberapa siswa yang tidak memiliki keyakinan untuk mengerjakan dan cenderung menolak untuk mengerjakan soal, hasil belajar para siswa tersebut pun tidak baik. Hal ini sejalan dengan hasil penelitian yang menunjukan adanya pengaruh kemampuan koneksi matematis dan disposisi matematis terhadap hasil belajar matematika. Hasil penelitian dalam penelitian ini sejalan dengan penelitian oleh Izzati (2017, p. 37) dengan hasil penelitian terdapat pengaruh koneksi dan disposisi matematis terhadap hasil belajar. Begitu pula dengan penelitian yang dilakukan oleh Mandur et al (2013, p. 70) dengan hasil penelitian bahwa kemampuan koneksi, kemampuan representasi, dan disposisisi matematis berkontribusi secara signifikan terhadap prestasi belajar matematika siswa kelas XI IPA di Kabupaten Manggarai, baik secara langsung maupun tidak langsung. Namun kontribusi koneksi matematis dan disposisi matematis terhadap hasil belajar pada penelitian tersebut sebesar $28,3 \%$ sedangkan pada penelitian ini kontribusi kemampuan koneksi matematis dan disposisi matematis terhadap hasil belajar sebesar 90,2\%. Dalam penelitian Widyawati (2016, p. 64) siswa yang mempunyai kemampuan koneksi matematis kategori tinggi memiliki prestasi belajar lebih baik dibandingkan siswa yang mempunyai kemampuan koneksi matematis kategori sedang dan rendah, serta siswa yang mempunyai kemampuan koneksi matematis kategori sedang memiliki prestasi lebih baik dibandingkan dengan siswa yang mempunyai kemampuan koneksi matematis kategori rendah.

\section{SIMPULAN}

Pada penelitian ini menguji adanya pengaruh kemampuan koneksi matematis dan disposisi matematis terhadap hasil belajar matematika 
36| Nadhifah, Susilo, Permatasari: Pengaruh Kemampuan Koneksi Matematis dan Disposisi ...

secara bersama-sama maupun secara masing-masing. Dari ketiga hipotesis yang telah diajukan ketiga-ketiga hipotesis diterima. Berikut adalah kesimpulan yang dapat diambil pada penelitian ini: (1) terdapat pengaruh kemampuan koneksi dan disposisi matematis terhadap hasil belajar matematika siswa; (2) terdapat pengaruh kemampuan koneksi matematis terhadap hasil belajar matematika siswa; (3) terdapat pengaruh disposisi matematis terhadap hasil belajar matematika siswa.

\section{DAFTAR PUSTAKA}

Arikunto, S. (2013). Dasar-dasar Evaluasi Pendidikan Edisi 2. Jakarta: Bumi Aksara.

Emzir. (2013). Metodologi Penelitian Pendidikan: Kuantitatif dan Kualitatif. Jakarta: PT. Rajagrafindo Persada.

Hasbullah. (2009). Dasar-Dasar Ilmu Pendidikan Ed. Revisi. Jakarta: PT. Rajagrafindo Persada.

Izzati, N. (2017). Pengaruh Kemampuan Koneksi dan Disposisi Matematis Terhadap Hasil Belajar Geometri Bidang Datar Mahasiswa IAIN Syekh Nurjati Cirebon. Eduma (Mathematics Education Learning And Teaching), 6(2), 33-40. https://doi.org/http://dx.doi.org/10.24235/eduma.v6i2.2231

Lestari, L. A., Suharto, \& Fatahillah, A. (2016). Analisis Pengaruh Disposisi Matematis terhadap Hasil Belajar Materi Integral Tak Tentu Siswa Kelas XII IPA 2 SMAN 4 Jember. Jurna Edukasi (JUKASI), 3(I), 40-43. https://doi.org/https://doi.org/10.19184/jukasi.v3i1.4320

Mandur, K., Sadra, I. W., \& Suparta, I. N. (2013). Kontribusi Kemampuan Koneksi, Kemampuan Representasi, dan Disposisi Matematis Terhadap Prestasi Belajar Matematika Siswa SMA Swasta di Kabupaten Manggarai. Jurnal Pendidikan Dan Pembelajaran Matematika, 2(1), 1-10. Retrieved from http://oldpasca.undiksha.ac.id/e-journal/index.php/JPM/article/view /885/639 
National Council Of Teachers Of Mathematics. (2000). Six Principles for School Mathematics. Retrieved March 2, 2017, from https://www.nctm.org/uploadedFiles/Standards_and_Positions/PSS

M_ExecutiveSummary.pdf

Sumarmo, U., Hidayat, W., Zukarnaen, R., Hamidah, \& Sariningsih, R.

(2011). Kemampuan dan Disposisi Berpikir Logis, Kritis, dan Kreatif Matematika (Eksperimen Terhadap Siswa SMA Menggunakan Pembelajaran Berbasis Masalah dan Strategi ThinkTalk-Write). Jurnal Pengajaran Matematika dan Ilmu Pengetahuan Alam, $17(1)$ 17-33. https://doi.org/http://dx.doi.org/10.18269/jpmipa.v17i1.228

Widyawati, S. (2016). Pengaruh Kemampuan Koneksi Matematis Siswa Terhadap Prestasi Belajar Matematika Ditinjau Dari Gaya Belajar Pada Materi Bangun Ruang Sisi Datar Siswa Kelas IX SMP Di Kota Metro. Iqra': Jurnal Kajian Ilmu Pendidikan, 1(1), 47-67. Retrieved from https://journal.iaimnumetrolampung.ac.id/ index.php/ji/article/view/33/43 
38| Nadhifah, Susilo, Permatasari: Pengaruh Kemampuan Koneksi Matematis dan Disposisi ... 